Southern Illinois University Carbondale

OpenSIUC

Publications

Center for Fisheries, Aquaculture, and Aquatic

Sciences

2010

\title{
Assessment of Otolith Chemistry for Identifying Source Environment of Fishes in the Lower Illinois River, Illinois
}

John M. Zeigler

Gregory Whitledge

Southern Illinois University Carbondale, gwhit@siu.edu

Follow this and additional works at: http://opensiuc.lib.siu.edu/fiaq pubs

\section{Recommended Citation}

Zeigler, John M. and Whitledge, Gregory. "Assessment of Otolith Chemistry for Identifying Source Environment of Fishes in the Lower Illinois River, Illinois." Hydrobiologia 638, No. 1 (Jan 2010): 109-119. doi:10.1007/s10750-009-0033-1.

This Article is brought to you for free and open access by the Center for Fisheries, Aquaculture, and Aquatic Sciences at OpenSIUC. It has been accepted for inclusion in Publications by an authorized administrator of OpenSIUC. For more information, please contact opensiuc@lib.siu.edu. 


\title{
Assessment of Otolith Chemistry for Identifying Source Environment of Fishes in the Lower Illinois River, Illinois.
}

\author{
John M. Zeigler and Gregory W. Whitledge ${ }^{1}$ \\ Fisheries and Illinois Aquaculture Center \\ Department of Zoology \\ and Center for Ecology
}

Southern Illinois University

Carbondale, IL 62901-6511

${ }^{1}$ Corresponding Author. Phone: (618) 453-6089; e-mail: gwhit@ siu.edu

Running Title: Otolith chemistry of Illinois River Fishes

Key Words: Otolith, microchemistry, stable isotopes, Illinois River, floodplain lakes, fish 


\begin{abstract}
Knowledge of habitats used by fish throughout their life history is important for management and conservation of riverine fish populations and habitats. Naturally occurring chemical markers in otoliths have recently been used to determine natal origins and environmental history of fishes in a variety of marine and freshwater environments. However, to our knowledge no studies have examined the applicability of this technique in large floodplain rivers in the U.S.A. We evaluated otolith microchemistry and stable isotopic composition as tools for determining origins of fishes in the lower Illinois River, its tributaries, and floodplain lakes. Fishes were collected from eight sites during summer 2006 and two additional sites in spring 2007. Water samples were obtained from these 10 sites plus one additional tributary during summer and fall 2006 and spring 2007. Otolith and water samples were analyzed for $\delta^{18} \mathrm{O}$ and a suite of trace elements; otoliths were also analyzed for $\delta^{13} \mathrm{C}$. Tributaries, floodplain lakes, and the Illinois River possessed distinct isotopic and elemental signatures, principally driven by differences in $\delta^{18} \mathrm{O}$ and $\delta^{13} \mathrm{C}$ among floodplain lakes, the Illinois River, and tributary streams. Otoliths reflected differences in water chemistry among habitats. Relationships between water and otolith $\delta^{18} \mathrm{O}$ and Sr:Ca were not significantly different among species, but some differences in relationships between water and otolith $\mathrm{Ba}: \mathrm{Ca}$ among species were detected. Linear discriminant function analysis with a leave-one-out jackknife procedure on otolith $\delta^{18} \mathrm{O}$ and $\delta^{13} \mathrm{C}$ indicated that fish may be classified back to environment (Illinois River, tributary, or floodplain lake) of capture with 80-98\% accuracy. Otolith microchemistry and stable isotope analyses provide a potentially effective means for determining recruitment sources and environmental history of fishes in the Illinois River. The ability to reconstruct environmental history of individual fish using naturally occurring isotopic markers in otoliths may also facilitate efforts to quantify nutrient and energy subsidies to the Illinois River provided by fishes that emigrate from floodplain lakes or tributaries.
\end{abstract}




\section{Introduction}

Knowledge of habitats used by riverine fishes throughout their life history is important for management and conservation of lotic fish populations and the habitats upon which they depend (Schlosser, 1991; Fausch et al., 2002). Many fishes in large, regulated rivers are thought to depend on connectivity between the river channel and floodplain lakes to access off-channel habitats for spawning and larval nursery (Bayley and Li, 1992; Gozlan et al., 1998; Nunn et al., 2007). Tributary streams may also contribute to fish assemblages in large rivers, at least near their confluences (Brown and Coon, 1994; Robinson et al., 1998; Kiffney et al., 2006). Primary and secondary channels within the river itself represent another potentially important recruitment source and larval nursery habitat for some riverine fishes (Humphries et al., 1999; Scheimer et al., 2001; Dettmers et al., 2001; Keckeis and Scheimer, 2002). Despite evidence that any of these habitats (floodplain lakes, tributaries, and river channel) may contribute substantially to reproduction and recruitment in riverine fish populations, their relative importance as natal environments for fishes in large rivers has not been quantified. Uncertainty regarding the relative importance of source habitats for fishes in large, regulated rivers indicates a need for new techniques to determine environmental history of individual fishes in these ecosystems.

Like many other large navigable rivers, the Illinois River, which flows from the Chicago, IL area southwesterly to its confluence with the Mississippi River near St. Louis, MO, historically had much interaction with its floodplain (Starrett, 1971). However, levee construction and channelization during the past century separated the Illinois River from almost half of its floodplain (Starrett, 1971). Many lakes that historically had at least some connectivity to the Illinois River now exhibit little to no connectivity with the river; many of these floodplain lakes have subsequently experienced high sedimentation rates (Starrett, 1971). The Illinois River was one of the most productive commercial fisheries in the early twentieth century (Pegg and McClelland, 2004). However, due in part to anthropogenic habitat modifications, Illinois River fish populations were greatly reduced (Starrett, 1971; Pegg and McClelland, 2004). Some restoration of connectivity between the Illinois River and floodplain lakes has been conducted in select locations (Reuter et al., 2005; Schultz et al., 2007), reducing 
floodplain lake sedimentation and providing fishes with access to these habitats for spawning and larval nursery (Csoboth and Garvey, 2008). However, the extent to which fishes produced in these restored floodplain lakes contribute to Illinois River fish populations is unknown. Restoration of river-floodplain lake connectivity may benefit both native and exotic fishes; connected floodplain lakes may be important source habitats for invasive Asian carps (bighead carp Hypophthalmichthys nobilis and silver carp H. molitrix) in the Illinois River (Pegg et al., 2002). However, Asian carps also spawn in the river's main channel (DeGrandchamp et al., 2007). Knowledge of the relative importance of the river channel and floodplain lakes to early life stages of Asian carps would be potentially valuable for developing strategies to control abundance of these exotic species that may be negatively affecting condition of native planktivorous fishes (Irons et al., 2007).

Microchemical and stable isotopic analyses of fish otoliths offer the potential to provide new insights into the relative importance of river channel, floodplain lake, and tributary habitats as source environments for fishes large, regulated rivers. Application of otolith trace element and isotopic compositions as natural tags has emerged as an effective technique for addressing questions regarding environmental history of freshwater fishes (e.g., Wells et al., 2003; Brazner et al., 2004; Dufour et al., 2005; Munro et al., 2005; Feyrer et al., 2007; Whitledge et al., 2007; Schaffler and Winkelman, 2008). Concentrations and stable isotopic compositions of some chemical elements in otoliths reflect those of environments occupied by a fish (e.g., Kennedy et al., 2002; Wells et al., 2003; Dufour et al., 2005; Whitledge et al., 2006) and are unaltered metabolically following deposition (Campana and Thorrold, 2001). Thus, association of otolith biochronology with isotopic and elemental composition enables retrospective description of fish environmental history when an individual has resided in chemically distinct locations for a period of time sufficient to incorporate the signature of those sites (Kennedy et al., 2002). Crook and Gillanders (2006) demonstrated the applicability of otolith microchemistry for identifying common carp recruitment sources in the Murray River, Australia. Stable isotopic composition of otoliths may also be useful for determining natal origin of fishes in freshwater environments and may distinguish fishes from locations that cannot be differentiated using otolith microchemistry (Dufour et al., 
2005; Whitledge et al., 2007). However, the applicability of otolith stable isotopic signatures as natural markers of fish environmental history in large river-floodplain ecosystems has not been assessed. Additionally, no studies have evaluated the applicability of otolith chemistry for identifying recruitment sources of fishes in the large, regulated rivers of the Midwestern United States.

The goal of this study was to determine whether otolith microchemistry and stable isotopic analyses may be useful tools for determining environmental history of fishes in the Illinois River, Illinois U.S.A. Specific objectives were to determine if water trace elemental and stable oxygen isotopic compositions differed among floodplain lakes, tributaries, and the Illinois River, to determine whether fish otolith microchemistry and isotopic compositions reflected those of environments (floodplain lakes, tributaries, and the Illinois River) in which they were captured, and to determine the accuracy with which individual fish could be reclassified to their collection locations based on otolith elemental and stable isotopic compositions. We also assessed whether relationships between water and otolith chemistry differed among fish species collected. Few studies have compared water-otolith chemistry relationships among species (Swearer et al., 2003; Hamer and Jenkins, 2007; Whitledge et al., 2007).

\section{Methods}

Fish and water samples were collected from 11 sites along the lower Illinois River (downstream from Peoria, IL; Fig. 1). These sites included two locations within the Illinois River channel (near Liverpool, Illinois, and Glades, Illinois), three tributaries of the lower Illinois River, and six backwater and floodplain lakes. Floodplain lakes included representatives with permanent and intermittent (during flooding) connections to the Illinois River and varied in the type of connection to the river (natural channel, ditch, or water control structure).

Two water samples were collected from each of the 11 sites during summer 2006 and again during both fall 2006 and spring 2007 to assess seasonal changes in stable isotopic and elemental compositions. One sample was collected during each season from each site for stable oxygen isotope analysis; a second water sample was collected seasonally from each site for analysis of a suite of twenty major, minor, and trace 
elements (including $\mathrm{Ca}, \mathrm{Sr}, \mathrm{Ba}, \mathrm{Mg}$, and $\mathrm{Mn}$ ). Water samples for stable oxygen isotope analysis were collected and stored in scintillation vials containing minimal air space and sealed with Parafilm to curtail evaporative loss and fractionation (Kendall and Caldwell, 1998). Water samples were analyzed for stable oxygen isotopic composition using a high-temperature conversion elemental analyzer (TC/EA) interfaced with a Thermo Finnigan Delta Plus $\mathrm{XL}^{\circledR}$ isotope ratio mass spectrometer. All stable isotope ratios were expressed in standard $\delta$ notation, defined as the parts per thousand deviation between the isotope ratio of a sample and standard material (Vienna Standard Mean Ocean Water):

$$
\delta^{18} \mathrm{O}(\%)=\left[\left(\mathrm{R}_{\text {sample }} / \mathrm{R}_{\text {standard }}\right)-1\right] \times 1000
$$

where R represents ${ }^{18} \mathrm{O} /{ }^{16} \mathrm{O}$. Mean standard deviation of replicate measurements of water $\delta^{18} \mathrm{O}$ was $0.23 \%$ o $(\mathrm{n}=3$ replicates per sample). Water samples for elemental analysis were collected using a syringe filtration technique described in Shiller (2003). Samples for analysis of elemental concentrations were stored on ice or refrigerated until overnight shipment and analysis by high-resolution, inductively coupled plasma mass spectrometry (HR-ICPMS) at the Center for Trace Analysis, University of Southern Mississippi.

Elemental concentration data were converted to molar element:calcium ratios (mmol/mol).

Fishes were collected from 10 sites during summer 2006 and spring 2007. Up to thirty individuals were collected from each site. Centrarchids (largemouth bass Micropterus salmoides, spotted bass M. punctulatus, green sunfish Lepomis cyanellus, bluegill L. macrochirus, orangespotted sunfish L. humilis, and black crappie Pomoxis nigromaculatus) were collected where possible due to their recreational importance and widespread availability; temperate basses (yellow bass Morone mississippiensis and white bass M. chrysops), and freshwater drum (Aplodinotus grunniens) were also collected from several sites. Fishes were captured by alternating current (AC) and direct current (DC) electrofishing and trap netting at sites where a boat could be launched. At sites without boat access, fishes were captured by seining or angling. Fishes were euthanized with MS-222, placed on ice for transport to the laboratory, and stored frozen until otolith removal.

Sagittal otoliths were removed from each fish using non-metallic forceps, rinsed with distilled water, and stored dry in polyethylene microcentrifuge tubes until 
preparation for analysis. One otolith from each fish was analyzed for stable oxygen and carbon isotopic composition. Otoliths $<1 \mathrm{mg}$ were pulverized whole with a mortar and pestle; material from the outer edge of otoliths $>1 \mathrm{mg}$ was subsampled and pulverized, as this portion of the otolith reflects a fish's most recent environmental history. Otoliths were analyzed for stable oxygen and carbon isotopic composition using a ThermoFinnigan Delta plus $\mathrm{XP}^{\circledR}$ isotope ratio mass spectrometer interfaced with a Gas Bench $\mathrm{II}^{\circledR}$ carbonate analyzer. Stable oxygen and carbon isotope ratios for otolith samples were expressed in standard $\delta$ notation $\left(\delta^{18} \mathrm{O}\right.$ or $\delta^{13} \mathrm{C}, \%$ ); mean standard deviation for replicate measurements ( $\mathrm{n}=2$ replicates per sample) was $0.8 \%$ for $\delta^{18} \mathrm{O}$ and $0.4 \%$ for $\delta^{13} \mathrm{C}$.

The second sagittal otolith from each fish was used for trace element ( $\mathrm{Sr}: \mathrm{Ca}$, $\mathrm{Ba}: \mathrm{Ca}, \mathrm{Mg}: \mathrm{Ca}, \mathrm{Mn}: \mathrm{Ca}$ ) analysis. Otoliths for trace element analysis were embedded in Epo-fix epoxy, sectioned in the transverse plane using an ISOMET low-speed saw, and then sanded and polished to reveal annuli. Otolith thin sections were prepared for analysis under a class 100 laminar flow hood and handled only with nonmetallic acidwashed forceps. Thin sections were mounted on acid-washed glass slides using doublesided tape, ultrasonically cleaned for $5 \mathrm{~min}$ in ultrapure water, and dried for $24 \mathrm{~h}$ under the laminar flow hood. Mounted and cleaned thin sections were stored in acid-washed polypropylene Petri dishes in a sealed container until analysis. Otolith thin sections were analyzed for ${ }^{88} \mathrm{Sr},{ }^{137} \mathrm{Ba},{ }^{24} \mathrm{Mg},{ }^{55} \mathrm{Mn}$, and ${ }^{44} \mathrm{Ca}$ using a Perkin-Elmer ELAN 6000 inductively coupled plasma mass spectrometer (ICPMS) coupled with a CETAC Technologies LSX-500 laser ablation system. The laser ablated a transect along the long axis of the otolith section from one side of the otolith core to the edge of the opposite side of the otolith (beam diameter $=25 \mu \mathrm{m}$, scan rate $=10 \mu \mathrm{m} / \mathrm{s}$, laser pulse rate $=10 \mathrm{~Hz}$, laser energy level $=9 \mathrm{~mJ}$, wavelength $=266 \mathrm{~nm}$ ). A standard developed by the U. S. Geological Survey (MACS-1, $\mathrm{CaCO}_{3}$ matrix) was analyzed every 12-15 samples to adjust for possible instrument drift. Each sample analysis was preceded by a gas blank measurement. Isotopic counts were converted to elemental concentrations $(\mu \mathrm{g} / \mathrm{g})$ after correction for gas blank, matrix, and drift effects. Mean limits of detection for ${ }^{88} \mathrm{Sr}$, ${ }^{137} \mathrm{Ba},{ }^{24} \mathrm{Mg}$, and ${ }^{55} \mathrm{Mn}$ were $0.06,0.35,0.66$, and $0.75 \mu \mathrm{g} / \mathrm{g}$, respectively; concentrations of these elements in all otoliths were well above detection limits. Otolith elemental 
concentrations were calculated from integrations over the final $10 \mathrm{~s}$ of laser ablation transects, as the outer portion of the otolith reflects a fish's most recent environmental history. Trace element concentrations were normalized to calcium $(\mathrm{Ca})$ concentration based on the consideration of $\mathrm{Ca}$ as a pseudointernal standard (Bickford and Hannigan, 2005; Ludsin et al., 2006); data are reported as element:Ca ratios (mmol/mol).

Least-squares linear regressions were used to characterize relationships between mean water and otolith signatures for each elemental or stable isotopic marker. ANCOVAs with Tukey's adjustment were applied to determine whether significant differences in otolith $\delta^{18} \mathrm{O}, \mathrm{Sr}: \mathrm{Ca}$ and $\mathrm{Ba}: \mathrm{Ca}$ were present among species; mean water $\delta^{18} \mathrm{O}, \mathrm{Sr}: \mathrm{Ca}$ and $\mathrm{Ba}: \mathrm{Ca}$ signatures from fish collection sites were used as covariates. Only species represented by $\geq 10$ individuals that were collected from floodplain lake, tributary, and riverine collection sites were included in ANCOVAs. To increase sample sizes for comparisons of otolith chemistry signatures among species, otolith and water $\delta^{18} \mathrm{O}, \mathrm{Sr}: \mathrm{Ca}$ and $\mathrm{Ba}: \mathrm{Ca}$ data from the nearby middle Mississippi River and upper Illinois River drainages were included in ANCOVAs (Whitledge, 2009; Zeigler, 2009).

Both univariate and multivariate approaches were used to assess differences in water and otolith trace element and stable isotopic signatures among individual sites and site types (floodplain lakes, tributaries, and the Illinois River). One way analyses of variance (ANOVAs) followed by Tukey's HSD test for multiple comparisons were used to assess differences in individual water and otolith chemistry parameters among sites and site types. Individual otolith chemistry parameters that differed significantly among sampling locations in conjunction with inter-site differences in water chemistry were entered into a multivariate analysis of variance (MANOVA) and a discriminant analysis (CANDISC procedure in $\mathrm{SAS}^{\circledR}$ ) to characterize the multivariate otolith chemistry signatures of the Illinois River, tributaries, and floodplain lakes; a plot of the first two canonical variates was used to visually depict differences among site types. Pillai's trace statistic was used to assess significance of differences in multivariate otolith chemistry signatures among the Illinois River channel, tributaries, and floodplain lakes. Additionally, linear discriminant function analysis with a leave-one-out jackknife procedure was used to determine the accuracy with which individual fish could be classified back to their environment of capture (Illinois River, tributary, or floodplain 
lake) based on their otolith chemical signatures. A p-value of $\leq 0.05$ was considered significant for all statistical tests.

\section{Results}

Mean water $\delta^{18} \mathrm{O}$ signatures were significantly different among site types (ANOVA, $\mathrm{F}=4.53, \mathrm{df}=2,29, \mathrm{p}=0.022$ ), with floodplain lake waters enriched in ${ }^{18} \mathrm{O}$ compared to the Illinois River (Fig. 2a). Tributary streams had an intermediate water $\delta^{18} \mathrm{O}$ signature that was not significantly different from that of floodplain lakes or the Illinois River (Fig. 2a). Mean water Sr:Ca values did not differ among site types (ANOVA, $\mathrm{F}=1.69, \mathrm{df}=2,29, \mathrm{p}=0.21$ ), but differed at the individual site level (ANOVA, $\mathrm{F}=2.73, \mathrm{df}=10,21, \mathrm{p}=0.0251$ ). One floodplain lake (Spring Lake, Tazewell County, Illinois) had significantly lower mean water Sr:Ca than all other sites, but no other sites differed among one another in water $\mathrm{Sr}: \mathrm{Ca}$. Mean water $\mathrm{Ba}: \mathrm{Ca}$ values differed among some individual sites (ANOVA, $\mathrm{F}=3.09 \mathrm{df}=10,21, \mathrm{p}=0.0142$ ) and among site types (ANOVA, $\mathrm{F}=17.31 \mathrm{df}=2,29, \mathrm{p}<0.0001$ ). Tributaries had higher water $\mathrm{Ba}$ :Ca values than floodplain lakes and the Illinois River, but mean water $\mathrm{Ba}$ :Ca did not differ between the Illlinois River and its floodplain lakes (Fig.3). Mean water Mg:Ca and Mn:Ca both exhibited significant differences among sites (ANOVA, $\mathrm{F}=2.45 \mathrm{df}=10,21, \mathrm{p}=0.0402$ and ANOVA, $\mathrm{F}=5.09 \mathrm{df}=10,21, \mathrm{p}=0.0008$, respectively), and mean water Mn:Ca differed among site types (ANOVA, $\mathrm{F}=5.70 \mathrm{df}=2,29, \mathrm{p}=0.0082$ ). However, we did not consider these two markers further due to non-significant relationships between otolith and water $\mathrm{Mg}: \mathrm{Ca}$ and Mn:Ca values (Mg:Ca: $\mathrm{r}^{2}=0.0455, \mathrm{p}=0.3285$; Mn:Ca: $\mathrm{r}^{2}=0.0334, \mathrm{p}=0.4037$ )

Otolith $\delta^{18} \mathrm{O}$ values were strongly correlated with water $\delta^{18} \mathrm{O}$ values $\left(\mathrm{r}^{2}=0.7084\right.$, $\mathrm{p}<0.0001$; Fig. 4). Mean otolith $\delta^{18} \mathrm{O}$ values were significantly different among site types (ANOVA, $\mathrm{F}=188.56 \mathrm{df}=2,88, \mathrm{p}<0.0001$ ), with otoliths of fishes from floodplain lakes enriched in ${ }^{18} \mathrm{O}$ compared to otoliths from fishes collected in the Illinois River and tributaries (Fig. 2b). Mean otolith $\delta^{13} \mathrm{C}$ values also displayed differences among site types (ANOVA, $\mathrm{F}=44.45 \mathrm{df}=2,90, \mathrm{p}<0.0001$ ), with otoliths from individuals collected in floodplain lakes enriched in ${ }^{13} \mathrm{C}$ compared to otoliths of fishes collected from the Illinois River and tributaries (Fig. 5). 
Both mean Sr:Ca values (Fig. 6) and mean Ba:Ca values (Fig. 7) in otoliths reflected mean water Sr:Ca and $\mathrm{Ba}: \mathrm{Ca}\left(\mathrm{r}^{2}=0.9247, \mathrm{p}<0.0001\right.$ and $\mathrm{r}^{2}=0.6178, \mathrm{p}<0.0001$, respectively) signatures. No significant differences in mean otolith $\mathrm{Sr}$ :Ca were detected among site types (ANOVA, $\mathrm{F}=1.17, \mathrm{df}=2,89, \mathrm{p}=0.32$ ), although mean otolith $\mathrm{Sr}: \mathrm{Ca}$ values differed at the individual site level (ANOVA, $F=12.92, \mathrm{df}=9,82, \mathrm{p}<0.0001$ ). Mean otolith Sr:Ca was significantly lower for one floodplain lake (Spring Lake) compared to all other sampling sites, consistent with differences in water $\mathrm{Sr}: \mathrm{Ca}$ among sites. However, mean otolith Sr:Ca was not significantly different among fish from any other individual sites. Mean otolith Ba:Ca values did not differ among site types (ANOVA, $\mathrm{F}=1.83, \mathrm{df}=2,89, \mathrm{p}=0.17$ ), although mean otolith $\mathrm{Ba}: \mathrm{Ca}$ dffered among some individual sampling sites (ANOVA, $\mathrm{F}=4.28, \mathrm{df}=9,82, \mathrm{p}=0.0001$ ).

Relationships between water and otolith $\delta^{18} \mathrm{O}$ and $\mathrm{Sr}$ :Ca were not significantly different among species ( $\mathrm{p}>0.05$ ) for all pair-wise comparisons. However, relationships between water and otolith $\mathrm{Ba}$ :Ca differed among some species. Mean freshwater drum $\mathrm{Ba}$ :Ca was significantly different $(\mathrm{p}<0.05)$ from all other fish species except spotted bass ( $\mathrm{p}=0.6616)$. Mean Ba:Ca for green sunfish was significantly different from that of bluegill ( $\mathrm{p}=0.0019)$ and orangespotted sunfish ( $\mathrm{p}=0.0357)$; mean Ba:Ca for largemouth bass was significantly different from that of bluegill $(\mathrm{p}=0.0011)$, orangespotted sunfish $(\mathrm{p}=0.0081)$, and yellow bass $(\mathrm{p}=0.0294)$.

Multivariate analysis of otolith data incorporating $\delta^{18} \mathrm{O}, \delta^{13} \mathrm{C}, \mathrm{Sr}: \mathrm{Ca}$, and $\mathrm{Ba}: \mathrm{Ca}$ indicated that fishes from the Illinois River, its tributaries, and floodplain lakes possessed significantly different otolith chemistry signatures (Pillai's Trace Statistic: F=13.99 $\mathrm{df}=8,138, \mathrm{p}<0.0001)$. A plot of the first two canonical variates from the CANDISC procedure in SAS illustrated the distinct otolith chemistry signatures among site types (Fig. 8). The first discriminant function (CAN1) from this model accounted for $99 \%$ of the total dispersion in the dataset. Otolith oxygen $\left(\delta^{18} \mathrm{O}\right)$ and carbon $\left(\delta^{13} \mathrm{C}\right)$ isotopic compositions were correlated with CAN1 (correlation coefficients of 0.97 and 0.73 , respectively; $\mathrm{p}<0.05)$, whereas otolith Sr:Ca was not associated with CAN1 ( $>>0.1)$, but was correlated with the second canonical variate (correlation coefficient of $0.89 ; \mathrm{p}<0.05$ ). Otolith Ba:Ca was not associated with CAN1 or CAN2 ( $>>0.05)$. Thus, $\delta^{18} \mathrm{O}$ and $\delta^{13} \mathrm{C}$ were the most important markers in defining otolith chemical fingerprints in multivariate 
discriminant space. Linear discriminant function analysis of otolith data incorporating $\delta^{18} \mathrm{O}$ and $\delta^{13} \mathrm{C}$ with a leave-one-out jackknife procedure indicated that individual fish could be classified back to their environment of capture (Illinois River, tributary, or floodplain lake) with 80-98 \% accuracy (Table 1). Neither the addition of otolith Sr:Ca nor otolith Ba:Ca data to the linear discriminant function analysis improved classification accuracy.

\section{Discussion}

Results indicated that fishes from the lower Illinois River, adjacent floodplain lakes, and tributary streams could be distinguished with a high degree of accuracy based on otolith $\delta^{18} \mathrm{O}$ and $\delta^{13} \mathrm{C}$. Fishes from a few individual sites also possessed distinct otolith $\mathrm{Sr}: \mathrm{Ca}$ and $\mathrm{Ba}: \mathrm{Ca}$ signatures. The naturally-occurring markers that best discriminated among fishes from the water bodies sampled in this study $\left(\delta^{18} \mathrm{O}\right.$ and $\delta^{13} \mathrm{C}$, and to a lesser extent $\mathrm{Sr}: \mathrm{Ca}$ and $\mathrm{Ba}: \mathrm{Ca}$ ) have frequently been among the most useful indicators of fish environmental history in other geographic locations (Gao et al., 2001; Wells et al., 2003; Brazner et al., 2004; Bickford and Hannigan, 2005; Dufour et al., 2005; Whitledge et al., 2007; Whitledge, 2009). Classification success rates for individual fish to environment of capture (Illinois River, tributary, or floodplain lake) in this study were comparable to or greater than those of published studies using otolith microchemistry and stable isotopic composition as indicators of source location for fishes in freshwater (Bronte et al., 1996; Wells et al., 2003; Brazner et al., 2004; Clarke et al., 2007; Schaffler and Winkelman, 2008; Whitledge, 2009), marine (Campana et al., 1995), and estuarine (Thorrold et al., 1998; Gillanders and Kingsford, 2000) environments. Most misclassifications in this study occurred among fishes from the Illinois River and tributaries; only one individual collected in a floodplain lake was incorrectly classified as having come from the Illinois River, reflecting the distinct $\delta^{18} \mathrm{O}$ and $\delta^{13} \mathrm{C}$ signatures of floodplain lake and lotic environments in this study. Some misclassifications of fish to environment of capture may have been due to the presence of recent immigrants (Whitledge, 2009).

Otolith isotopic and elemental compositions were strongly correlated with corresponding water values and reflected differences in water $\delta^{18} \mathrm{O}, \mathrm{Sr}: \mathrm{Ca}$, and $\mathrm{Ba}: \mathrm{Ca}$ 
among the Illinois River, its tributaries, and floodplain lakes and among individual sampling locations. Significant correlations between water and otolith signatures for these three naturally occurring chemical markers are consistent with results of prior studies (Patterson et al., 1993; Wells et al., 2003; Walther and Thorrold, 2008). Observed differences in water and otolith $\delta^{18} \mathrm{O}$ between the Illinois River and its floodplain lakes are likely due primarily to the greater opportunity for evaporative fractionation (Hoefs, 2004) to be expressed in floodplain lakes as a result of their longer water residence times relative to the Illinois River. Whitledge et al. (2007) found similar differences in water $\delta \mathrm{D}$ (which undergoes similar fractionation processes) between floodplain ponds and the upper Colorado River due to higher evaporation rates of pond water. Otolith $\delta^{13} \mathrm{C}$ also distinguished fishes from the Illinois River and its floodplain lakes, with otolith $\delta^{13} \mathrm{C}$ values for individuals collected in floodplain lakes enriched in ${ }^{13} \mathrm{C}$ compared to fishes collected from riverine environments. Mechanisms responsible for observed differences in otolith $\delta^{13} \mathrm{C}$ among environments sampled in this study are unknown. Otoliths incorporate both dissolved inorganic carbon (DIC) and metabolically-derived carbon (Kalish, 1991; Solomon et al., 2006). Observed differences in otolith $\delta^{13} \mathrm{C}$ likely reflect differences in $\delta^{13} \mathrm{C}$ of DIC between floodplain lake and riverine habitats; $\delta^{13} \mathrm{C}$ of DIC in the Illinois River and tributaries is unknown, but is likely influenced by isotopically light respired carbon (Hoefs, 2004) from upstream municipal wastewater (e.g., from the Chicago metropolitan area) and other sources. Floodplain lake DIC might also be enriched in ${ }^{13} \mathrm{C}$ compared to that of the Illinois river due to higher rates of photosynthesis by aquatic primary producers or because the longer water residence time in floodplain lakes may enable equilibration of DIC with atmospheric $\mathrm{CO}_{2}$ (Hoefs, 2004). Mechanisms responsible for the few observed differences in water and otolith Sr:Ca and Ba:Ca among locations sampled in this study are also unclear. Spring Lake's significantly lower Sr:Ca signature is likely due to its unique water source (groundwater from the Mahomet Aquifer) compared to other floodplain lakes and tributary streams sampled. Other observed differences in $\mathrm{Ba}$ :Ca signatures among sampling locations are likely due to local variation in bedrock geology (Wells et al., 2003).

Regardless of the mechanisms responsible for differences in water and otolith elemental and isotopic compositions among our sampling locations, multi-parameter 
chemical "fingerprints" in otoliths established in this study will be useful for distinguishing among fishes from the lower Illinois River, its tributaries, and floodplain lakes if observed differences in environmental signatures persist in future years. Other studies have reported interannual stability in otolith isotopic and trace elemental signatures in some freshwater environments (Zimmerman and Reeves, 2002; Wells et al., 2003; Dufour et al., 2005; Munro et al., 2005; Ludsin et al., 2006; Whitledge et al., 2007; but see Schaffler and Winkelman, 2008). Mean water $\delta^{18} \mathrm{O}$ values for the Illinois River ($5.9 \% \neq \pm 1.0 \% \mathrm{SE})$ and tributaries $(-4.3 \% \mathrm{o} \pm 0.7 \% \mathrm{SE})$ during this study was within the ranges of $\delta^{18} \mathrm{O}$ values reported by Coplen and Kendall (2000) for the Illinois River and other streams in Illinois and Missouri, respectively during November 1984-August 1987; these results suggest that the Illinois River and tributary $\delta^{18} \mathrm{O}$ signatures are relatively stable across years. Summer 2006 water $\delta^{18} \mathrm{O}$ values for the Illinois River were enriched in ${ }^{18} \mathrm{O}$ compared to $\delta^{18} \mathrm{O}$ values reported by Coplen and Kendall (2000), perhaps due to the relatively warm, dry summer during 2006. However, floodplain lakes and the Illinois River possessed distinct $\delta^{18} \mathrm{O}$ signatures that were reflected in fish otoliths despite some seasonal variation in water $\delta^{18} \mathrm{O}$. Floodplain lakes differed among one another in their connectivity with the Illinois River, but all exhibited a distinct multivariate, isotopic signature that enabled highly accurate identification of individual fish captured in floodplain lakes based on otolith $\delta^{18} \mathrm{O}$ and $\delta^{13} \mathrm{C}$. Major floods would likely eliminate distinctions between the Illinois River and its floodplain lakes, although the effect of a short-duration flood (particularly one that occurs outside of the growing season) on otolith chemical signatures may be minimal. Substantial inter-annual variation in environmental signatures may preclude the use of otolith chemistry for distinguishing among fish of floodplain lake, tributary, and riverine origin during some years or may require a "library" of environmental signatures and separate classification models for assigning natal origin to fish from different year classes (Ludsin et al., 2006; Schaffler and Winkelman, 2008).

We found no significant differences in relationships between water and otolith $\delta^{18} \mathrm{O}$ and $\mathrm{Sr}$ :Ca signatures among the fish species collected in this study, consistent with the findings of some prior studies (Patterson et al., 1993; Whitledge et al., 2007). Differences in mean otolith $\delta^{18} \mathrm{O}, \delta^{13} \mathrm{C}$, and $\mathrm{Sr}$ :Ca among site types were consistent 
among species. Most of the fish species collected in this study were centrarchids, which may account for the lack of significant differences in relationships between water and otolith $\delta^{18} \mathrm{O}$ and $\mathrm{Sr}$ :Ca among species. In contrast, species-specific incorporation of trace elements ( $\mathrm{Mg}, \mathrm{Mn}, \mathrm{Sr}$, and $\mathrm{Ba}$ ) into otoliths has been noted in other studies (Swearer et al., 2003; Hamer and Jenkins, 2007). Additional research should assess differences in relationships between otolith and environmental stable isotopic and microchemical signatures among fish species. While our findings suggest that models for determining environmental history of a particular fish species may sometimes be applicable to closely related species, water-otolith chemistry relationships should not be applied broadly across taxa without verification of their consistency among species.

The accuracy with which we were able to classify fish back to their environment of capture (Illinois River, tributary or floodplain lake) demonstrates the potential applicability of otolith oxygen and carbon isotopic compositions for determining recruitment sources and environmental history of fishes in the lower Illinois River drainage. Otolith microchemistry or stable isotopic composition have been successfully applied to distinguish fish of floodplain lake and riverine origin in other river systems (Crook and Gillanders, 2006; Whitledge et al., 2007). Estimating the relative contributions of floodplain lake, tributary, and riverine habitats to fish populations in the lower Illinois River appears feasible via analysis of naturally occurring chemical signatures in otoliths. Otolith stable isotopic signatures may be useful for identifying recruitment sources of both native fishes and exotic species such as bighead and silver carp; however, characterization of relationships between water and otolith chemical signatures for these species would be required. The ability to reconstruct environmental history of individual fish using naturally occurring isotopic markers in otoliths may also facilitate efforts to quantify nutrient and energy subsidies to the Illinois River provided by fishes that immigrate to the river from floodplain lakes or tributaries (Polis et al., 1997).

\section{Acknowledgments}

Funding for this research was provided by a faculty seed grant from the Office of Research Development and Administration, Southern Illinois University-Carbondale. 
Stable isotope analyses of water and otolith samples were performed by the Alaska Stable Isotope Facility, University of Alaska-Fairbanks. Trace element analyses of water samples were conducted by the Center for Trace Analysis, University of Southern Mississippi. We thank Ian Ridley and Alan Koenig (U. S. Geological Survey Mineral Resources Team, Denver, Colorado) for access to the LA-ICPMS laboratory and for providing analytical support. We also thank Maureen Doran for access to the laminar flow hood and we thank Nick Wahl for assisting with collecting fishes. 


\section{References}

Bayley, P. B. \& H. W. Li, 1992. Riverine fishes. In: Calow, P. \& G. E. Petts, (eds.), The Rivers Handbook. Vol. 1. Blackwell Scientific Publications, Oxford: 251-281.

Bickford, N. \& R. Hannigan, 2005. Stock identification of walleye via otolith chemistry in the Eleven Point River, Arkansas. North American Journal of Fisheries Management 25: 1542-1549.

Brazner, J. C., S. E. Campana \& D. K. Tanner, 2004. Habitat fingerprints for Lake Superior coastal wetlands derived from elemental analysis of yellow perch otoliths. Transactions of the American Fisheries Society 133: 692-704.

Bronte, C. R., R. J. Hesselberg, J. A. Shoesmith \& M. H. Hoff, 1996. Discrimination among spawning concentrations of Lake Superior lake herring based on trace element profiles in sagittae. Transactions of the American Fisheries Society 125: 852-859.

Brown, D. J. \& T. G. Coon, 1994. Abundance and assemblage structure of fish larvae in the lower Missouri River and its tributaries. Transactions of the American Fisheries Society 123: 718-732.

Campana, S. E. \& S. R. Thorrold, 2001. Otoliths, increments, and elements: keys to a comprehensive understanding of fish populations? Canadian Journal of Fisheries and Aquatic Sciences 58: 30-38.

Campana, S. E., J. A. Gagne \& J. W. McLaren, 1995. Elemental fingerprinting of fish otoliths using ID-ICPMS. Marine Ecology Progress Series 122: 115-120.

Clarke, A. D., K. H. Telmer \& J. M. Shrimpton, 2007. Elemental analysis of otoliths, fin rays and scales: a comparison of bony structures to provide population and lifehistory information for the Arctic grayling (Thymallus arcticus). Ecology of Freshwater Fish 16: 354-361.

Coplen, T. B. \& C. Kendall, 2000. Stable hydrogen and oxygen isotope ratios for selected sites of the U. S. Geological Survey's NASQAN and BENCHMARK surface water networks. U. S. Geological Survey open-file report 00-160, Reston, VA: 424 pp. 
Crook, D. A. \& B. M. Gillanders, 2006. Use of otolith chemical signatures to estimate carp recruitment sources in the Mid-Murray River, Australia. River Research and Applications 22: 871-879.

Csoboth, L. A. \& J. E. Garvey, 2008. Lateral exchange of larval fish between a restored backwater and a large river in the East-Central USA. Transactions of the American Fisheries Society 137: 33-44.

DeGrandchamp, K. L., J. E. Garvey \& L. A. Csoboth, 2007. Linking adult reproduction and larval density of invasive carp in a large river. Transactions of American Fisheries Society 136: 1327-1334.

Dettmers, J. M., D. H. Wahl, D. A. Soluk \& S. Gutreuter, 2001. Life in the fast lane: fish and food web structure in the main channel of large rivers. Journal of the North American Benthological Society 20: 255-265.

Dufour, E., W. P. Patterson, T. O. Hook \& E. S. Rutherford, 2005. Early life history of Lake Michigan alewives (Alosa pseudoharengus) inferred from intra-otolith stable isotope ratios. Canadian Journal of Fisheries and Aquatic Sciences 62: 2362-2370.

Fausch, K. D., C. E. Torgersen, C. V. Baxter \& H. W. Li, 2002. Landscapes to riverscapes: bridging the gap between research and conservation of stream fishes. BioScience 52:483-498.

Feyrer, F., J. Hobbs, M. Baerwald, T. Sommer, Q. Yin, K. Clark, B. May \& W. Bennett, 2007. Otolith microchemistry provides information complementary to microsatellite DNA for a migratory fish. Transactions of the American Fisheries Society 136: 469-476.

Gao, Y. W., S. H. Joner \& G. G. Bargmann, 2001. Stable isotopic composition of otoliths in identification of spawning stocks of Pacific herring (Clupea pallasi) in Puget Sound. Canadian Journal of Fisheries and Aquatic Sciences 58: 2113-2120.

Gillanders, B. M. \& M. J. Kingsford, 2000. Elemental fingerprints of otoliths of fish may distinguish estuarine 'nursery' habitats. Marine Ecology Progress Series 201: 273286. 
Hamer, P. A. \& G. P. Jenkins, 2007. Comparison of spatial variation in otolith chemistry of two fish species and relationships with water chemistry and otolith growth. Journal of Fish Biology 71: 1035-1055.

Hoefs, J., 2004. Stable Isotope Geochemistry. Springer-Verlag, Berlin.

Humphries, P., A. J. King \& J. D. Koehn, 1999. Fish, flows and floodplains: links between freshwater fish and their environment in the Murray-Darling River system, Australia. Environmental Biology of Fishes 56: 129-151.

Irons, K. S., G. G. Sass, M. A. McClelland \& J. D. Stafford, 2007. Reduced condition factor of two native fish species coincident with invasion of non-native Asian carps in the Illinois River, U.S.A. Is this evidence for competition and reduced fitness? Journal of Fish Biology 71: 258-273.

Kalish, J. M., 1991. Oxygen and carbon stable isotopes in the otoliths of wild and laboratory-reared Australian salmon (Arripis trutta). Marine Biology 110: 37-47.

Keckeis, H. \& F. Scheimer, 2002. Understanding conservation issues of the Danube River. In Fishery Science: The Unique Contribution of Early Life Stages, Fuiman LA, Werner RG (eds). Blackwell Publishing, Oxford: 272-288.

Kendall, C. \& E. A. Caldwell, 1998. Fundamentals of isotope geochemistry. In: Kendall, C. \& J. J. McDonnell, (eds.), Isotope Tracers in Catchment Hydrology, Elsevier, Amsterdam: 51-86.

Kennedy, B. P., A. Klaue, J. D. Blum, C. L. Folt \& K. H. Nislow, 2002. Reconstructing the lives of fish using $\mathrm{Sr}$ isotopes in otoliths. Canadian Journal of Fisheries and Aquatic Sciences 59: 925-929.

Kiffney, P. M., C. M. Greene, J. E. Hall \& J. R. Davies, 2006. Tributary streams create spatial discontinuities in habitat, biological productivity, and diversity in mainstem rivers. Canadian Journal of Fisheries and Aquatic Sciences 63: 25182530.

Ludsin, S. A., B. J. Fryer \& J. E. Gagnon, 2006. Comparison of solution-based versus laser ablation inductively coupled plasma mass spectrometry for analysis of larval fish otolith microelemental composition. Transactions of the American Fisheries Society 13: 218-231. 
Munro, A. R., T. E. McMahon \& J. R. Ruzycki, 2005. Natural chemical markers identify source and date of an exotic species: lake trout (Salvelinus namaycush) in Yellowstone Lake. Canadian Journal of Fisheries and Aquatic Sciences 62: 79-87.

Nunn, A. D., J. P. Harvey \& I. G. Cowx, 2007. Benefits to 0+ fishes of connecting manmade waterbodies to the lower River Trent, England. River Research and Applications 23: 361-376.

Patterson, W. P., G. R. Smith \& K. C. Lohmann, 1993. Continental paleothermotry and seasonality using the isotopic composition of aragonitic otoliths of freshwater fishes. In: Swart, P., K. Lohmann, J. McKenzie \& S. Savin, (eds.), Climate change in continental isotopic records. Geophysical Monograph 78. American Geophysical Union. Washington, DC: 191-202.

Pegg, M. A., A. M. Lemke \& J. A. Stoeckel, 2002. Establishment of bighead carp in an Illinois River floodplain lake: A potential source population for the Illinois River. Journal of Freshwater Ecology 17: 161-163.

Pegg, M. A. \& M. A. McClelland, 2004. Spatial and temporal patterns in fish communities along the Illinois River. Ecology of Freshwater Fish 13: 125-135.

Polis, G. A., W. B. Anderson \& R. D. Holt, 1997. Toward an integration of landscape and food web ecology: the dynamics of spatially subsidized food webs. Annual Review of Ecology and Systematics 28: 289-316.

Reuter, M., K. Lubinski, P. West, D. Blodgett \& M. Khoury, 2005. The Nature Conservancy's approach to conserving and rehabilitating biological diversity in the Upper Mississippi River system. Archiv für Hydrobiologia Supplementband 155: 549-560.

Robinson, A. T., R. W. Clarkson \& R. E. Forrest, 1998. Dispersal of larval fishes in a regulated river tributary. Transactions of the American Fisheries Society 127: $772-786$.

Schaffler, J. J. \& D. L. Winkelman, 2008. Temporal and spatial variability in otolith trace-element signatures of juvenile striped bass from spawning locations in Lake Texoma, Oklahoma-Texas. Transactions of the American Fisheries Society 137: 818-829. 
Schiemer, F., H. Keckeis, W. Reckendorfer \& G. Winkler, 2001. The 'inshore retentivity concept' and its significance for large rivers. Archiv fur Hydrobiologie Supplement b 135: 509-516.

Schlosser, I. J., 1991. Stream fish ecology: a landscape perspective. BioScience 41:704712.

Schultz, D. W., J. E. Garvey \& R. C. Brooks, 2007. Backwater immigration by fishes through a water control structure: implications for connectivity and restoration. North American Journal of Fisheries Management 27: 172-180.

Shiller, A. M., 2003. Syringe filtration methods for examining dissolved and colloidal trace element distributions in remote field locations. Environmental Science and Technology 37: 3953-3957.

Solomon, C. T., P. K. Weber, J. J. Cech, Jr., B. L. Ingram, M. E. Conrad, M. V. Machavaram, A. R. Pogodina \& R. L. Franklin, 2006. Experimental determination of the sources of otolith carbon and associated isotopic fractionation. Canadian Journal of Fisheries and Aquatic Sciences 63: 79-89.

Starrett, W. C., 1971. Man and the Illinois River. In: Oglesby, R. T., C. A. Carlson \& J.A. McCann (eds.), River Ecology and the Impact of Man. Academic Press, New York, NY: 131-169.

Swearer, S. E., G. E. Forrester, M. A. Steele, A. J. Brooks \& D. W. Lea, 2003. Spatiotemporal and interspecific variation in otolith trace-elemental fingerprints in a temperate estuarine fish assemblage. Estuarine, Coastal and Shelf Science 56: 1111-1123.

Thorrold, S. M., C. M. Jones, P. K. Swart \& T. E. Targett, 1998. Accurate classification of juvenile weakfish Cynoscion regalis to estuarine nursery areas based on chemical signatures in otoliths. Marine Ecology Progress Series 173: 253-265.

Walther, B. D. \& S. R. Thorrold, 2008. Continental-scale variation in otolith geochemistry of juvenile American shad (Alosa sapidissima). Canadian Journal of Fisheries and Aquatic Sciences 65: 2623-2635. 
Wells, B. K., B. E. Rieman, J. L. Clayton, D. L. Horan \& C. M. Jones, 2003. Relationships between water, otolith, and scale chemistries of westslope cutthroat trout from the Coeur d' Alene River, Idaho: the potential application of hard-part chemistry to describe movements in freshwater. Transactions of the American Fisheries Society 132: 409-424.

Whitledge, G. W., 2009. Otolith microchemistry and isotopic composition as potential indicators of fish movement between the Illinois River drainage and Lake Michigan. Journal of Great Lakes Research 35: 100-105.

Whitledge, G. W., B. M. Johnson \& P. J. Martinez, 2006. Stable hydrogen isotopic composition of fishes reflects that of their environment. Canadian Journal of Fisheries and Aquatic Sciences 63: 1746-1751.

Whitledge, G. W., B. M. Johnson, P. J. Martinez \& A. M. Martinez, 2007. Sources of non-native centrarchids in the upper Colorado River revealed by stable isotope and microchemical analyses of otoliths. Transactions of the American Fisheries Society 136: 1263-1275.

Zeigler, J. M., 2009. Utility of otolith microchemistry and stable isotopic composition for determining fish environmental history in the Mississippi and Illinois Rivers. M.S. Thesis, Southern Illinois University-Carbondale: 72 pp.

Zimmerman, C. E. \& G. H. Reeves, 2002. Identification of steelhead and resident rainbow trout progeny in the Deschutes River, Oregon, revealed with otolith microchemistry. Transactions of the American Fisheries Society 131: 986-993. 
Table 1. Results of linear discriminant function analysis showing classification accuracy (determined by jackknife procedure) for individual fish to environment of collection based on otolith $\delta^{18} \mathrm{O}$ and $\delta^{13} \mathrm{C}$.

\begin{tabular}{lcccc}
\hline & \multicolumn{3}{c}{ Assigned Location } & \\
\cline { 2 - 4 } $\begin{array}{l}\text { Source } \\
\text { Location }\end{array}$ & $\begin{array}{c}\text { Floodplain } \\
\text { lakes }\end{array}$ & Tributaries & Illinois River & $\begin{array}{c}\% \\
\text { Correct }\end{array}$ \\
\hline Floodplain lakes & 53 & 0 & 1 & 98 \\
Tributaries & 0 & 16 & 1 & 94 \\
Illinois River & 0 & 4 & 16 & 80 \\
\hline
\end{tabular}




\section{List of Figures}

Fig. 1. Map showing locations where water samples and fishes were collected for this study.

Fig. 2. a) Mean water $\delta^{18} \mathrm{O}$ values $( \pm \mathrm{SE})$ for the Illinois River, tributaries, and floodplain lakes and $b$ ) mean otolith $\delta^{18} \mathrm{O}$ values $( \pm \mathrm{SE})$ for fish collected from the Illinois River, tributaries, and floodplain lakes. Within each panel, means that are marked with the same letter are not significantly different (ANOVA followed by Tukey's HSD test, $\mathrm{p}>0.05$ ).

Fig. 3. Mean water Ba:Ca values $( \pm S E)$ for the Illinois River, tributaries, and floodplain lakes. Means that are marked with the same letter are not significantly different (ANOVA followed by Tukey's HSD test, $\mathrm{p}>0.05$ ).

Fig. 4. Linear regression of mean otolith $\delta^{18} \mathrm{O}$ on mean water $\delta^{18} \mathrm{O}$. Data points are means \pm SE.

Fig. 5. Mean otolith $\delta^{13} \mathrm{C}$ values $( \pm \mathrm{SE})$ for fish collected from the Illinois River, tributaries, and floodplain lakes. Means that are marked with the same letter are not significantly different (ANOVA followed by Tukey’s HSD test, $\mathrm{p}>0.05$ ).

Fig. 6. Linear regression of mean otolith Sr:Ca on mean water Sr:Ca. Data points are means \pm SE.

Fig. 7. Linear regression of mean otolith $\mathrm{Ba}: \mathrm{Ca}$ on mean water $\mathrm{Ba}: \mathrm{Ca}$. Data points are means \pm SE.

Fig. 8. Plot of the first two canonical variates obtained through linear discriminant function analysis including otolith $\delta^{18} \mathrm{O}, \delta^{13} \mathrm{C}, \mathrm{Sr}: \mathrm{Ca}$, and $\mathrm{Ba}: \mathrm{Ca}$. 
Sampling Sites

- Illinois River

- Tributaries

$\checkmark$ Floodplain lakes

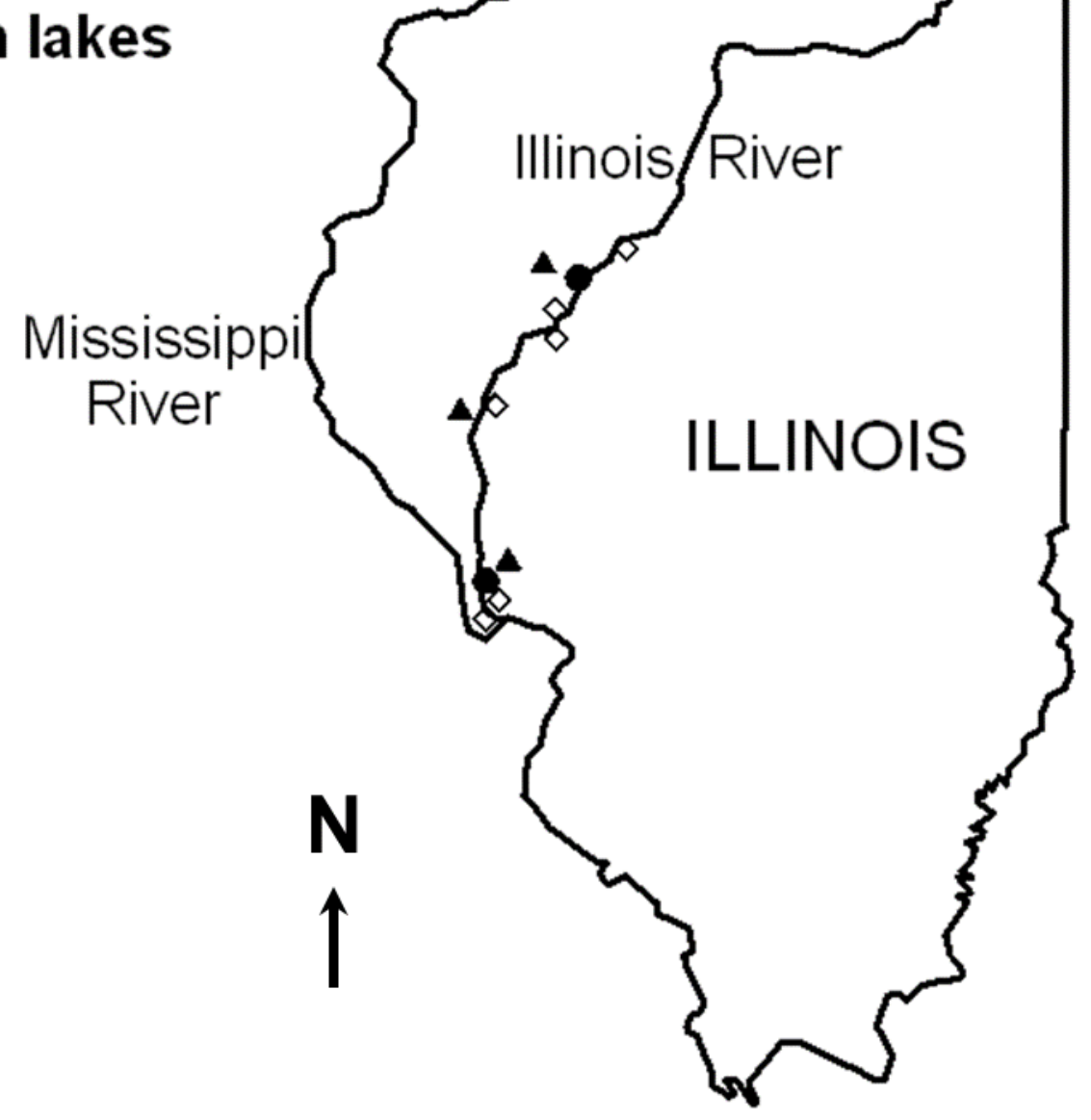



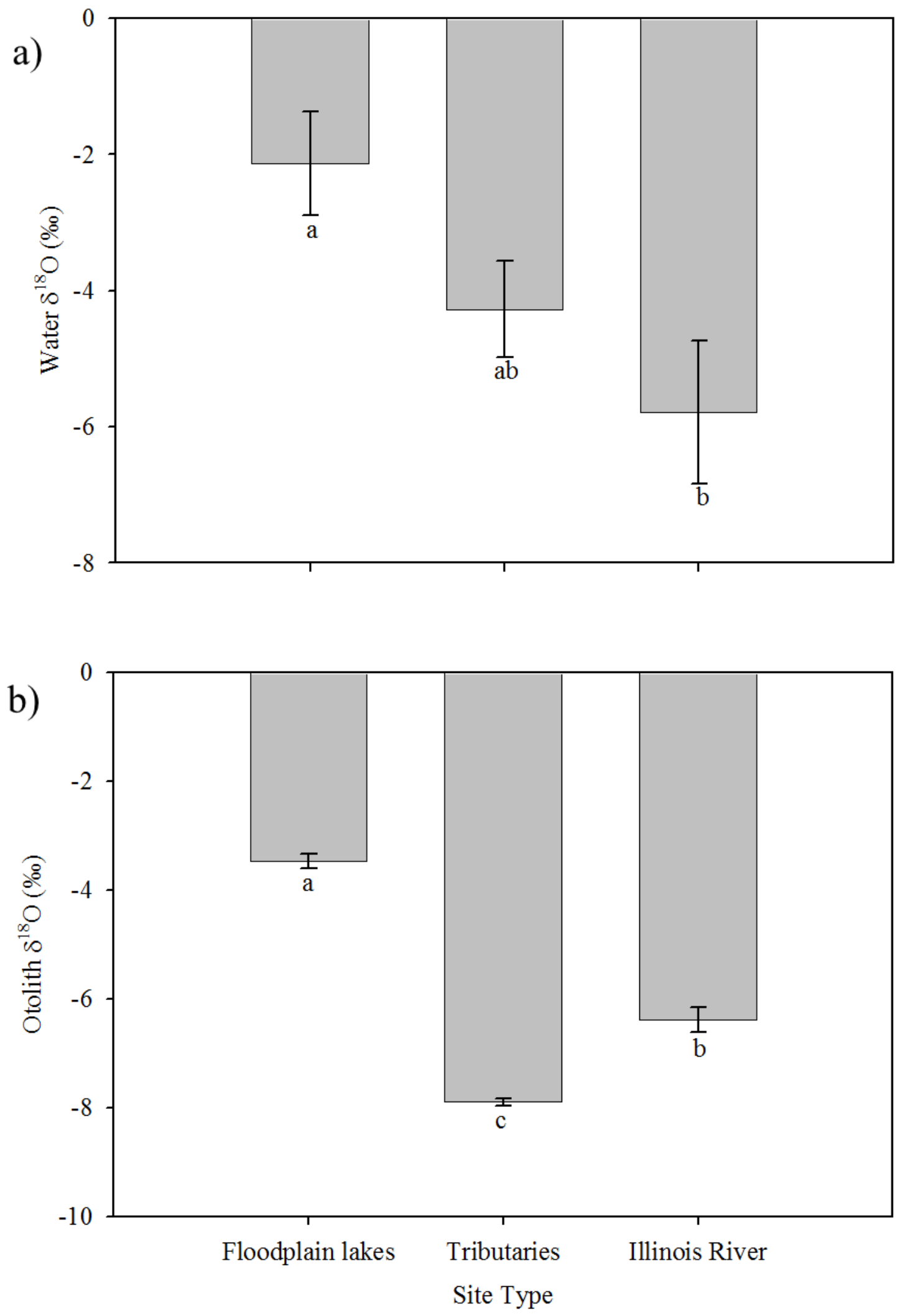


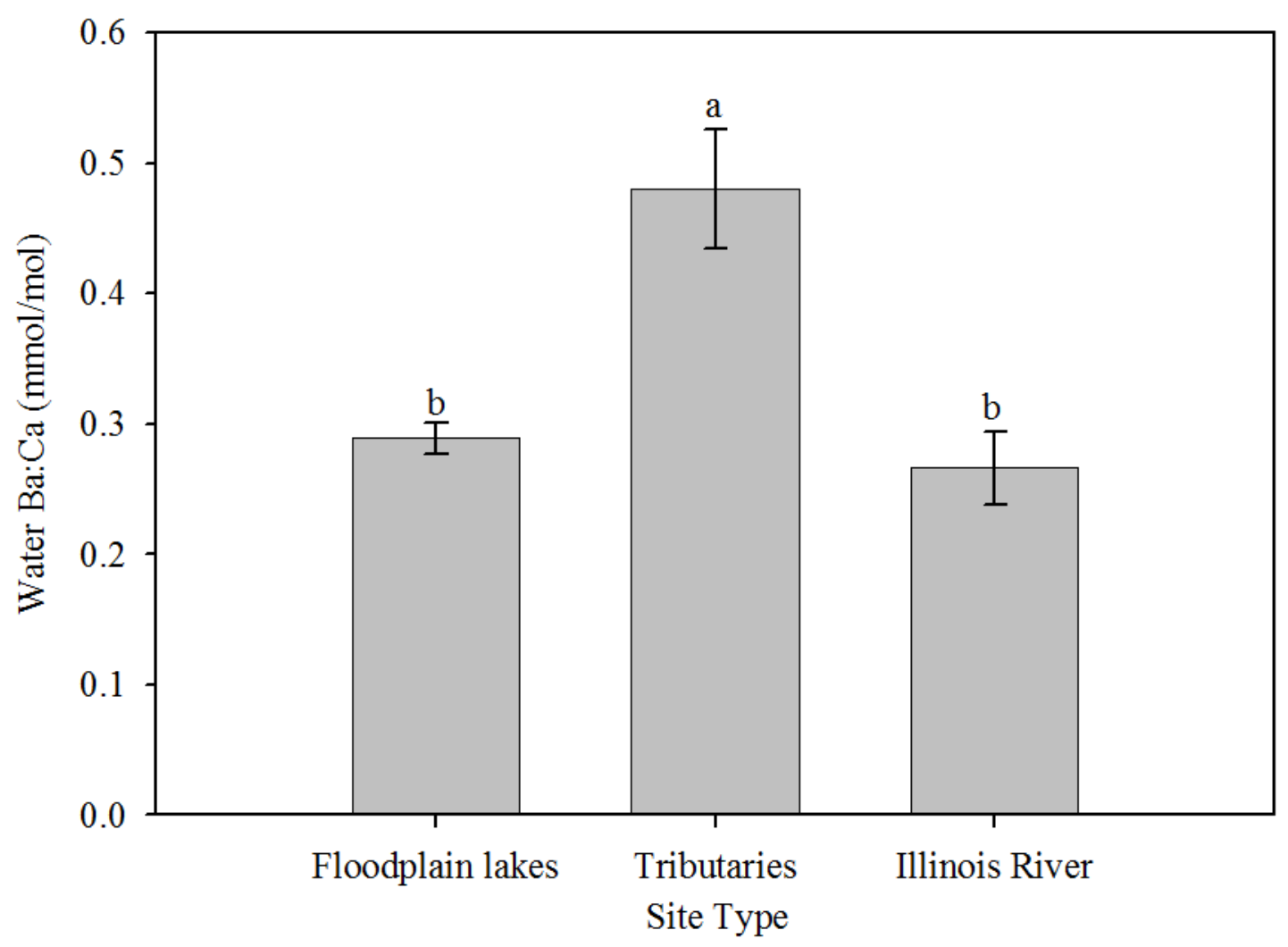




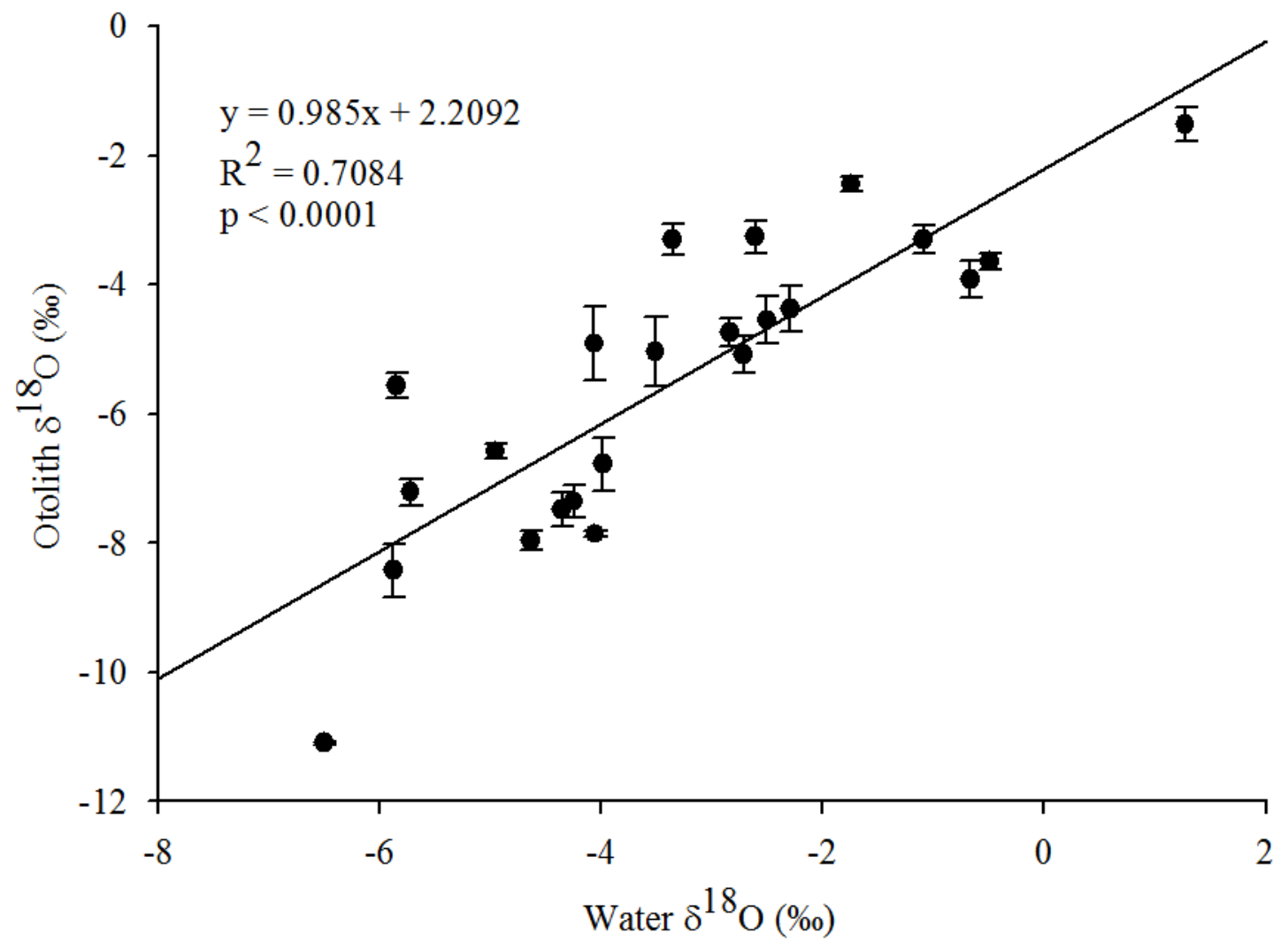




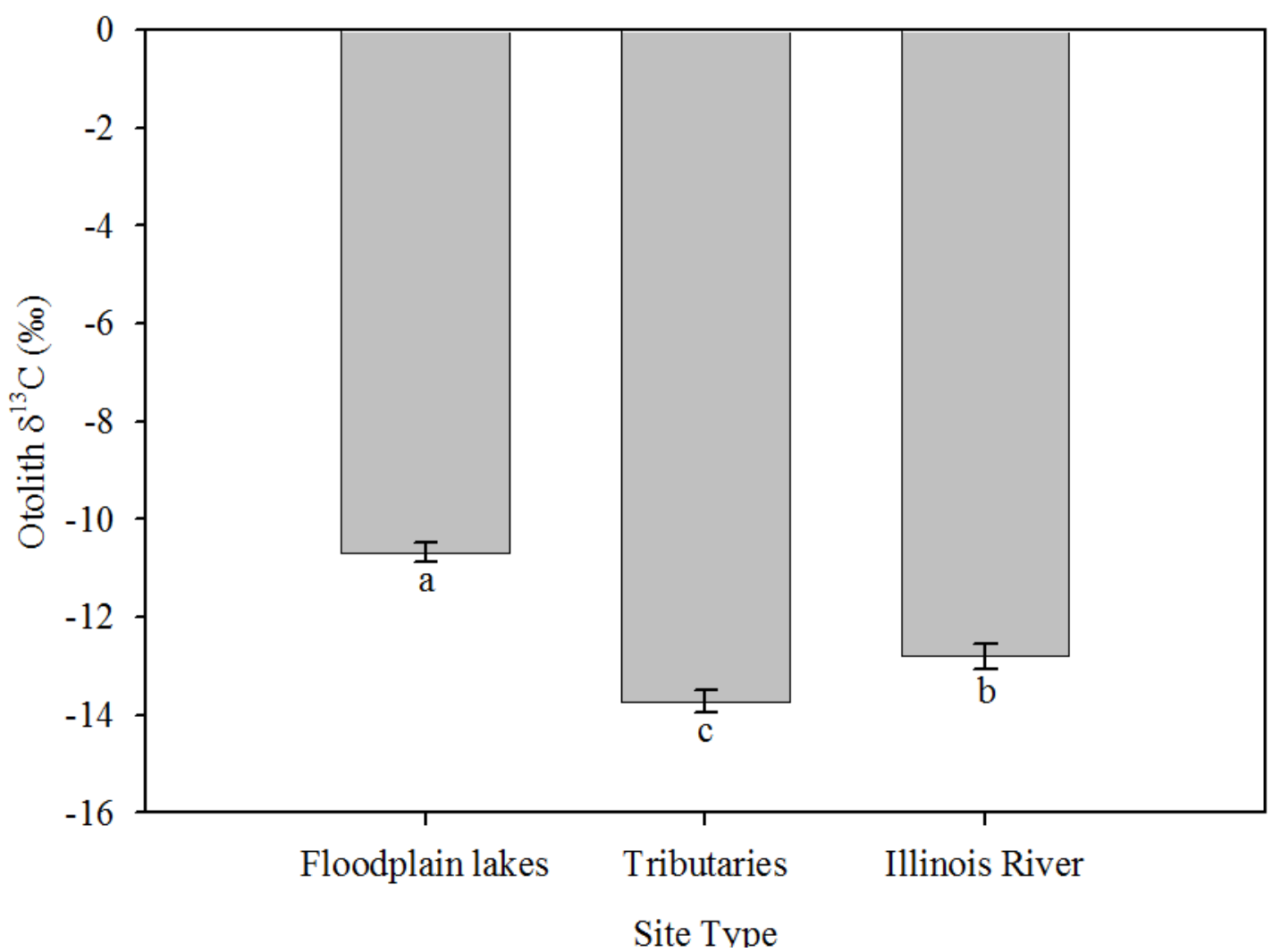




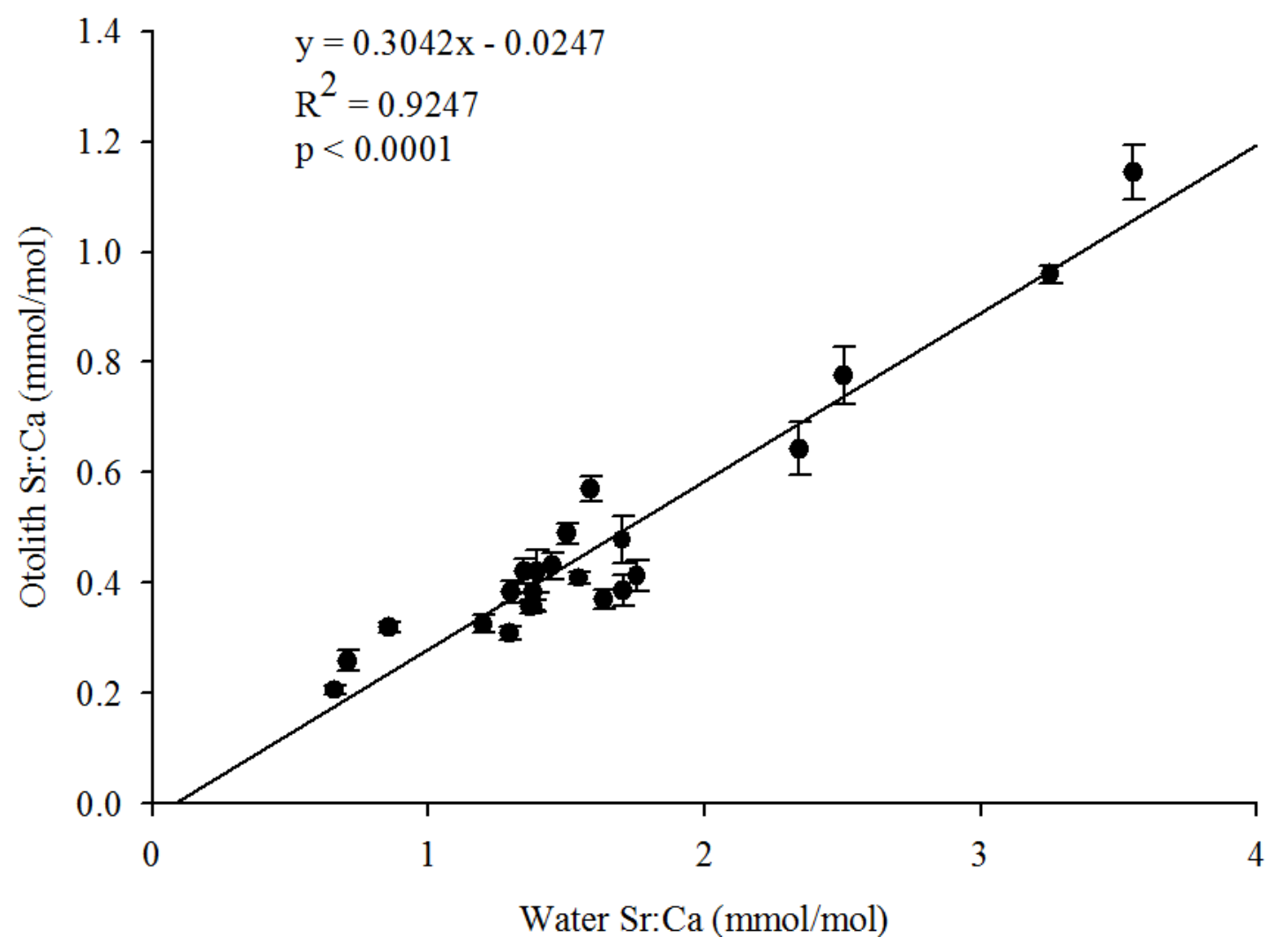




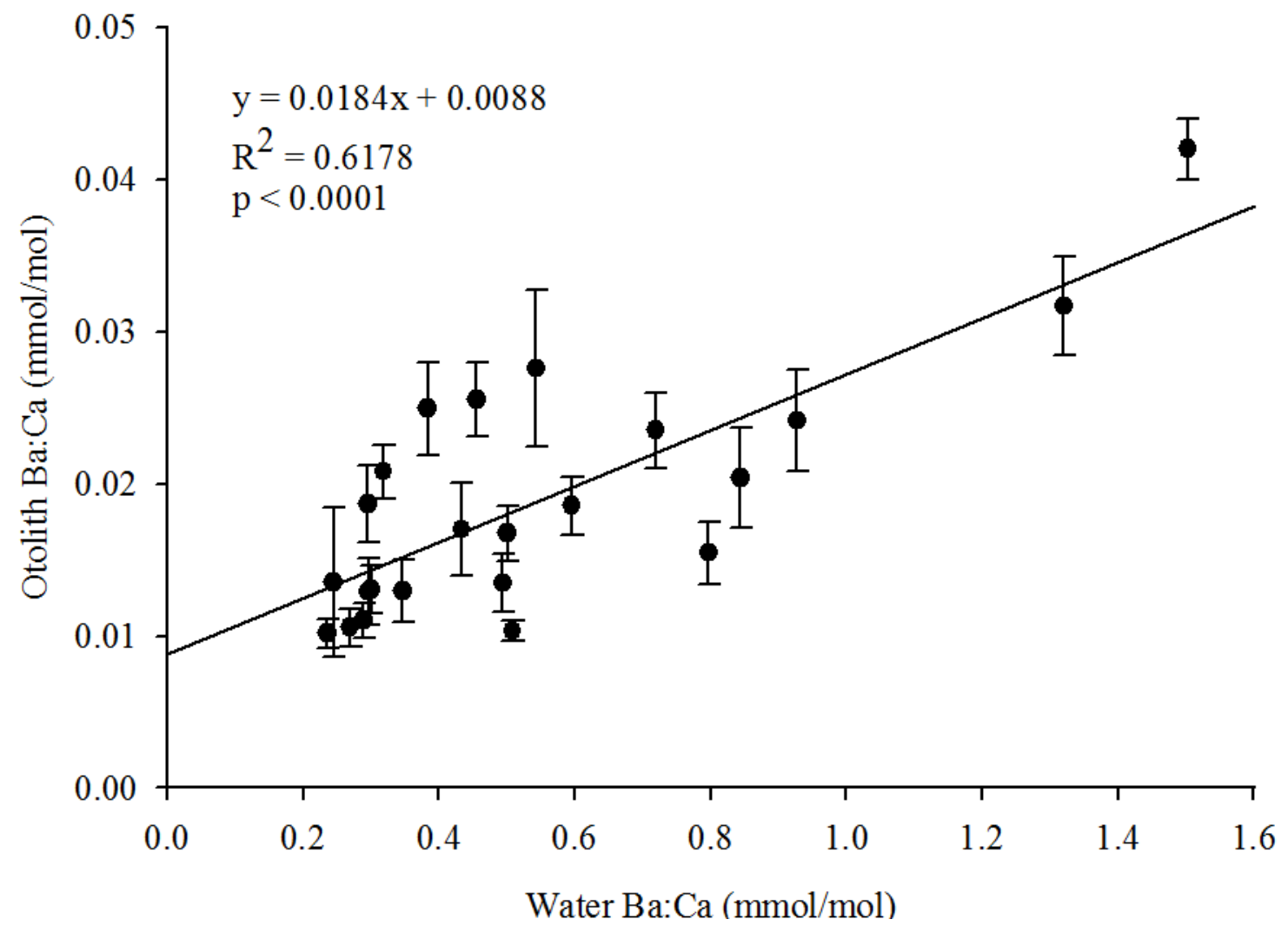




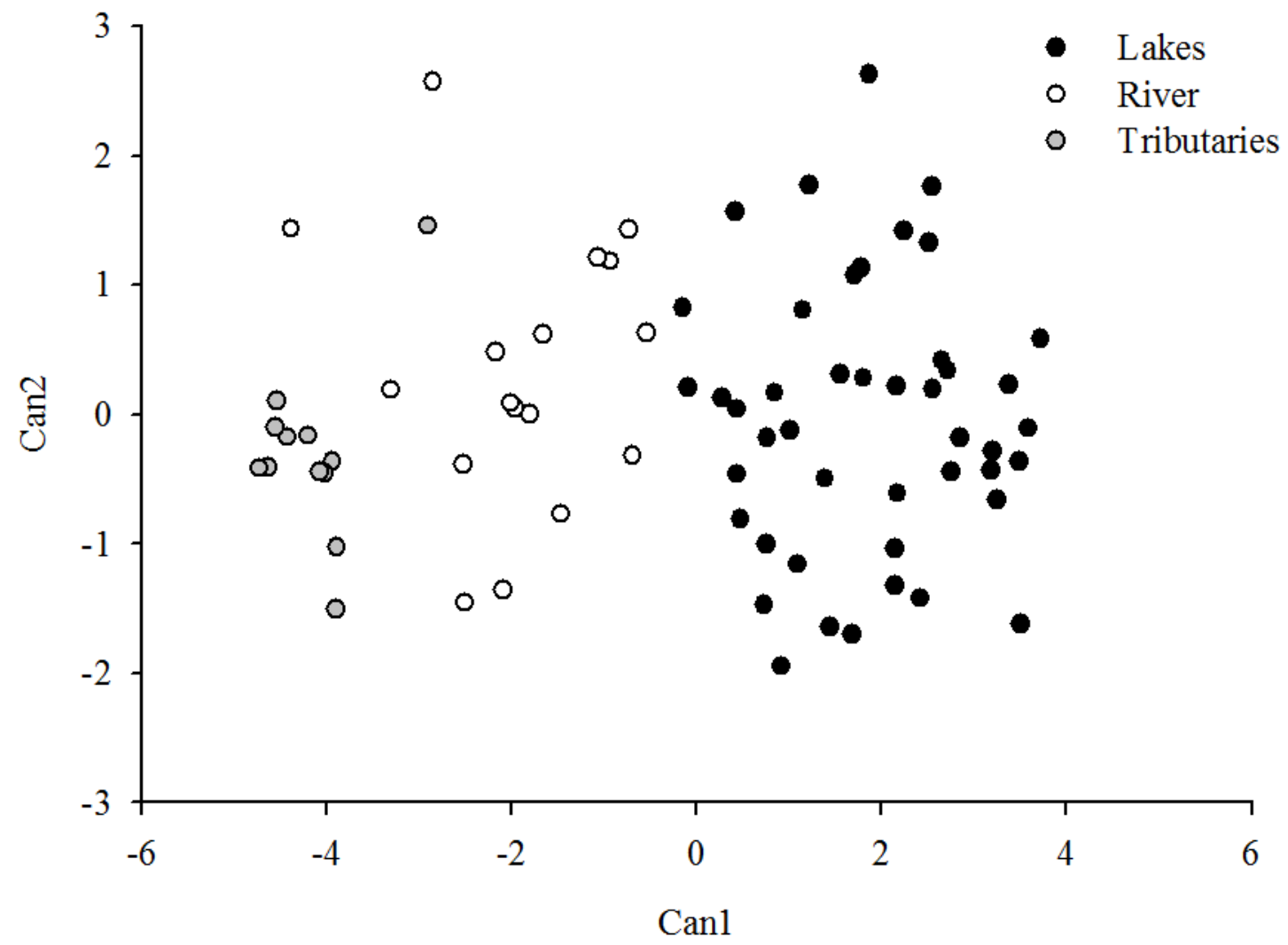

